\title{
Meeting the challenge of poverty and inequality? 'Hindrances and helps' with regard to congregational mobilisation in South Africa
}

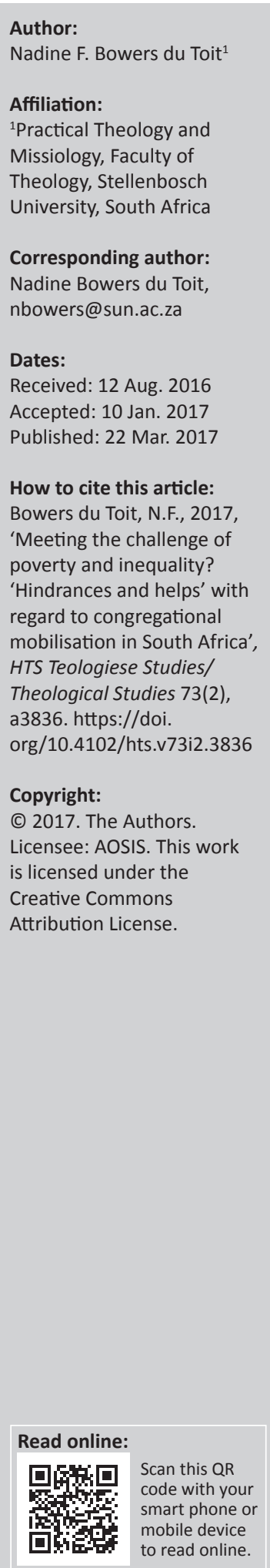

The findings of an empirical study entitled 'Meeting the challenge of poverty and inequality in the Cape Metropole: Factors impacting the mobilisation of congregations in their response to poverty and injustice' reaffirm that the majority of congregations are still largely operating within a 'relief and welfare' paradigm with regard to poverty. In attempting to analyse the hindrances to churches' mobilisation in addressing poverty from a holistic perspective, it became clear that, while there were common challenges (such as lack of capacity and feeling overwhelmed in view of the enormity of the task), several other intersectional issues (e.g. race, class and theological convictions) also play a role with regard to engagement. This article, therefore, analyses and discusses how these factors have an impact on the mobilisation of local congregations in their response to the twin challenge of poverty and inequality.

\section{Introduction}

Although congregations as local expressions of faith communities have, for the most part, delivered social services to local communities, they have not always been as well studied or recognised as the religious social service agencies/faith-based organisations $(\mathrm{FBOs})^{1}$ that make development work their focus (Chaves \& Tsitos 2001:664; Todd \& Allen 2011:222). ${ }^{2}$ In recent years, however, the focus has shifted towards the local congregation particularly in relation to social and spiritual capital discourse. Such a discourse recognises the influence of religious motivation in sustaining involvement and financial contributions of the congregations. This recognition has seen congregations being increasingly acknowledged for their contribution to social services (Swart 2012:291). In ecumenical circles, the World Council of Churches (WCC) Busan Congress appeared to distinctly refocus its diaconal work more purposefully towards the local congregation as both 'diaconal community' and 'subjects' of development. Gill (2014:249) notes that, in the past, ecumenical diaconia had often treated local congregations as 'objects to which diaconia resources were orientated and to which diaconia resources and expertise from outside were given'. Phiri and Dongsung (2014), however, find that a shift has clearly taken place:

Therefore, it is important that the local congregations as well as the national institutional structures of the
church 'recognise diaconia as an essential expression' of being church in the world today. The WCC,
through its recognition and support, encouragement and accompaniment of the local expressions of
transformative and prophetic diaconia can expand the network of pilgrims. Likewise by proactively
expressing their vocation as diaconal communities, local congregations can become the subjects of the
pilgrimage of justice and peace ... (p. 260)

Nevertheless, international studies maintain that many congregations continue to operate in what may be termed as 'charity' or 'relief and welfare' mode. These may include soup kitchens, volunteerism in homeless programmes as well as food banks and donations to charity (Chaves \& Tsitos 2001:671). Additionally, Chaves and Tsitos (2001:672) note that projects or small-scale programmes that 'are able to take advantage of congregation's capacity to mobilise relatively small numbers of volunteers to carry out well-defined and bounded tasks' are most common in congregational engagement. Such relief or charity engagement has often been critiqued by both local and international diaconia scholars as possessing the potential for harmful relationships of dependency - despite its necessity (Jeavons 2000; Todd \& Allen 2011:222). It is interesting to note, therefore, that despite an upsurge in interest within WCC circles and elsewhere on the role of the local congregation, there remains a struggle to move beyond what David Korten calls 'first and

1.It is important to note that I do not include congregations here as part of a definition of faith-based organisations.

2.In South Africa, although local congregations have been the subject of study, local congregations as agents of social mobilisation with regard to poverty and inequality has not been as widely researched. 
second generation' approaches (Bowers Du Toit \& Nkomo 2014; cf. Swart \& Venter 2001). This may well be grounded on Farnsley's (2003:69) argument that the expectations regarding US congregations to deliver is unfounded as there is an 'abundance of evidence' that points to congregations 'difficulty sustaining community development and delivering social welfare services'. Here, the South African church's struggle to move beyond this paradigm results from both the lack of professionalised capacity as well as struggle to engage the roots of poverty and inequality, which are inherently tied to injustice (cf. Bowers du Toit \& Nkomo 2014:8; Swart 2012:295).

A study conducted by Chaves and Tsitos (2001:673) in the United States found that better resourced and larger congregations were able to do more social services and that 'college educated people do more social services'. The study also noted that most congregational diaconia was done in collaboration with other organisations such as non-governmental organisations (NGOs), ${ }^{3}$ FBOs $^{4}$ and government agencies. Perhaps most interesting for this study was the finding that 'congregations are not equally likely to collaborate' owing to theological differences and understandings around civic engagement (Chaves \& Tsitos 2001:675, 676).

Based on the findings of a qualitative study entitled: 'Meeting the challenge of poverty and inequality in the Cape Town Metropolis: Factors impacting the mobilisation of congregations in their response to poverty and injustice,, 5 conducted between 2014 and 2015, this article seeks to explore what I term 'hindrances' ${ }^{6}$ and 'helps ${ }^{77}$ to congregational mobilisation with regard to poverty and inequality. To this end, the article briefly discusses the motivation of the study and the methodology employed, followed by the current modes of engagement and the key findings.

\section{Motivation and methodology}

This study was done in partnership with a FBO called 'The Warehouse $^{\prime 8}$ that works in the area of church mobilisation. The Warehouse had just undergone a strategic shift towards church mobilisation and away from projects, so as a scholar

3.NGOS are "private, self-governing, non-profit organisations promoting people centred development' (Davids, Theron \& Kealeboga 2009:68).

4.FBOs are more often than not NGOs; however, there is also a degree of complexity attached to the signifier of ' $F B O$ ' as it is often broadly used to refer to a broad range of faith-based actors which according to Clarke (2006:840) include faith-based representative organisations, faith-based charitable or development organisations, representative organisations, faith-based charitable or development organisations, even faith-based illegal or terrorist organisations. In this case study, FBO will refer to faith-based development organisations.

5.This project sought to explore congregations' self-understandings with regard to poverty and the church's engagement as well as investigated the possible influence of factors such as race, class and denomination on the church's mobilisation with regard to poverty alleviation. This is my own research project, which was completed with the assistance of Mawethu Ncaca.

6.Those factors that hinder mobilisation.

7.Those factors that help or assist in congregational mobilisation.

8.The Warehouse's vision reads as follows: 'We long to see just and transformed communities where the vulnerable are cared for because the local church is a transformed and transformative presence. The Warehouse seeks to achieve its vision by inspiring, equipping and connecting churches to become a transforming vision by inspiring, equipping and connecting churches to become a transforming
and transformative presence in their communities that effectively address poverty, and transformative presence in their commun
injustice and division' (The Warehouse n.d.). and board member, I hoped the study could serve their work. To this end, both the research question and the objectives of the study were brainstormed together with the staff of this organisation. The issue of what form conscientisation efforts took (and the content) with regard to the mobilisation of congregations also appeared to be a 'gap' both in the literature and the practitioner's knowledge within South Africa. The project, therefore, sought to explore congregations' selfunderstandings with regard to poverty and the church's engagement. Besides, the project aimed to investigate the possible influence of factors such as theology, race, socioeconomic factors, class and denominational grouping, on the church's mobilisation in poverty alleviation. This article specifically focuses on hindrances and helps to mobilisation. ${ }^{9}$

The study was qualitative in nature as it sought to generate 'rich' data through semi-structured interviews with the clergy seeking to understand their perspectives as leaders of congregations. ${ }^{10}$ Fifteen congregational leaders in total were interviewed from a wide range of geographical areas, class, race and denominational persuasions. ${ }^{11}$ Ethical clearance was obtained through the university and the interviews adhered to the principle of anonymity to protect the respondents. I conducted the interviews as the project leader with the help of a research assistant. A pilot study was conducted in which the first two interviews were used to serve that purpose. The most interesting part of this research is its methodological process considering that both the research assistant and I were involved in the coding process of the data. ${ }^{12}$ We first coded separately then compared our coding and came to a consensus. Thematic analysis was conducted, and ATLAS.ti was used to assist in this process. Although the process led to some interesting contrasts in perspective, it also served to strengthen or highlight some of the more salient findings. This brought a thicker perspective particularly because the analysis was done by two researchers from different racial and denominational traditions.

Other findings of this study will be published elsewhere. The article also looks at current modes of engagement as a background to the reflected findings. The findings were also presented to interested respondents, the clergy and Christian development practitioners, at an open feedback session in an attempt to engage them.

\section{Current modes of engagement}

Congregations are engaging with poverty in diverse ways. However, as findings from both national and international

9.It should be noted that the project also sought to focus on how race, class and theology possibly intersect, which is why constant reference is also made to those factors.

10.Ethical clearance to conduct this study was obtained through the University of Stellenbosch, and all procedures were followed with regard to confidentiality, anonymity and consent. All interviews were recorded and transcribed.

11.Denominations and groups represented in this study included the Anglican, Dutch Reformed, Baptist, Independent Evangelical, Independent Neo-Pentecostal and Methodist churches. The sampling frame arose from a database of congregations that have had contact with The Warehouse. Sampling was conducted by the Department of Statistics of the Stellenbosch University.

12. Mawethu Ncaca, my research assistant, should be acknowledged here for his assistance. 
studies in recent years indicate, much of their engagement is characterised by what is termed as 'relief and charity' approaches. Several congregations, particularly those in poorer areas, ran either soup kitchens or provided food parcels $(\operatorname{Rev} 1, \operatorname{Rev} 8, \operatorname{Rev} 3, \operatorname{Rev} 4)$. These were targeted at the community in general or towards more vulnerable members of the community such as HIV sufferers, orphaned and vulnerable children (OVC) or the homeless. Although some noted that they felt they were not doing enough or it was not sustainable, they also emphasised that without this assistance survival would have been more difficult for the intended recipients. Some noted that they were aware this was relief and not empowerment and their ideal in terms of engagement was, in fact, empowerment rather than relief. This is what Rev 3 had to say in this regard:

'We have times where we hand them some...some parcels, some food parcels. Of course we know [sic]t cannot eliminate poverty, yabona. ${ }^{13}$ The ... the way we do things is to empower them and help them to see that $[\mathrm{sic}]$... I can do better yebona ... in life, yebona. I can do better.'

Rev 3's views were echoed by other ministers in township communities who sought ways to put job seekers, for example, in touch with possible jobs or opportunities which could enhance access to the job market. In this way, ministers in poorer communities often serve as a type of advice office for those in the community requiring referrals or in need of access to services, jobs, grants or documentation. This was viewed as tied to empowerment as Rev 4 reports:

'So it's doing that kind of thing, identifying with ... helping people to realise that they can do something about their situation. If you're well enough, able enough, you can do something.'

Wealthier congregations also appeared to lean towards providing advice office type of services, but these are based in either poorer communities or what one could term 'catchment areas' for vulnerable sectors of the South African society such as refugees ( $\operatorname{Rev} 8, \operatorname{Rev} 5)$. It was particularly interesting to note that a congregation based in a township area, but with both wealthy, professional members and poorer members, used this as a means of asset-based community development:

'... there are people working and they have got high positions and then they will come with applications, there's this bursary for those who have got matric, there's this internship training and then there's intake on such and such a day. I'll be responsible and now here are the forms, fill the forms I'll help you to fill in the forms and I'll take in the forms and I will also be one of the people who will be interviewing you. And indeed there are many people who have got work here and then I always say people in your position wherever you are, you know there's somebody here who doesn't have work - do something about that. And then there are people, this child cannot go to school, even to register, let us help that child to register.' (Rev 4)

Congregations also appeared to focus on projects related to children, such as reading programmes, Early Childhood Development and the care of orphaned and vulnerable children (OVC) in their communities ( $\operatorname{Rev} 4, \operatorname{Rev} 6, \operatorname{Rev} 3$, Rev 12). Here, it was interesting to note that one township church had established a bursary scheme (Rev 9). Similarly, two congregations, one from a wealthy suburb and another from an impoverished area, were also seen to partner with regard to initiatives such as vocational training, for example, computer skills and tutoring during the holidays ( $\operatorname{Rev} 5$, Rev 8). Such partnerships, however, did not seem common as reflected in the findings discussed below.

Wealthier congregations or congregations based in socioeconomically diverse areas often sought to partner with NGOs, FBOs or government services such as the South African Police Service in addressing the issues in their communities such as homelessness or trauma ( $\operatorname{Rev} 6, \operatorname{Rev} 5, \operatorname{Rev} 10)$. The latter is also true in terms of congregational networking through an ecumenical initiative such as the Christian Council of Churches (CCC) ${ }^{14}$ disaster response team, which is led by an FBO. Two churches in particular (both in socio-economically diverse areas with diverse congregations in terms of race and class) preferred to refer to missional engagement rather than poverty initiatives or projects ( $\operatorname{Rev} 6, \operatorname{Rev} 4)$. In such initiatives, the aim was not the provision of a social service but rather the notion of relationship building with the diverse 'other'.

\section{Hindrances to congregational mobilisation}

The findings of the study in terms of hindrances to congregational mobilisation were not unexpected. Several respondents mentioned that the issue of poverty and related socio-economic challenges was simply overwhelming for many laity. As a result, some churches either choose to disengage completely or simply engage in a charity mode of soup kitchens or clothing collection. This was also related to the issue of fear where many people (especially wealthier laity) did not know where or how to begin ( $\operatorname{Rev} 5 ; \operatorname{Rev} 2$, Rev 11). One minister noted:

'There's fear, fear of the unknown, fear of crime, fear of stories that they have heard about homeless people or poor people, or driving at night you know simple things like that ...' (Rev 11)

This minister put this down to the ignorance of others' realities. Another minister noted:

'What will happen if I go into that community? Will somebody shoot me? Will I be robbed and attacked? Will I be stoned because I'm a white person? There's a lot of fear amongst white people in our country today.' (Rev 5)

This was taken further where racial and socio-economic prejudices were mentioned. Rev 5, a minister of a wealthy macro congregation, went further to even mention that people often have superiority complexes and can continue to live in their suburban cocoon with no need to cross-cultural or socio-economic boundaries.

14.The Christian Council of Churches is an ecumenical body of church leaders in the Cape Metropole. These leaders may be identified as both from the mainline and evangelical streams. 
Time constraint was mentioned by several respondents in middle class to wealthier congregations $(\operatorname{Rev} 5, \operatorname{Rev} 6, \operatorname{Rev} 8$, Rev 11). This was problematic especially for middle and upper class young families as well as professionals but was problematised by others as being rooted in individualism. As it were, individualism is complicated by the difficulty that such a group has in identifying with the poor. This was particularly noted by Rev 6 as being prevalent in suburban areas:

'In the suburban areas we don't know our neighbours. We can continue $\ldots$ and so we live in a culture today that lives as individuals and so those that live in poverty, that side, I can no longer identify myself with them.'

This apathy and individualism were also connected by one minister from a majority wealthy white congregation to laity viewing the congregation itself as a 'service provider', such that church becomes only a place where one receives rather than gives $(\operatorname{Rev} 5)$.

In poorer communities, a culture of entitlement and dependency was noted. This was linked to mental poverty particularly in cases where people believe that they could not do much out of their own initiative. It was also linked to a culture of dependency created by wealthy people/ donors. One Manenberg pastor mentioned that white people's guilt was not the answer: 'it doesn't help people if you have a lot of people from the affluent white churches (in his denomination) and they always want to be doing something for Manenberg' (Rev 4). This may appear harsh but as the pastor explained, this could be viewed as creating complacency and dependency. Such arrangements prevent the poor from breaking the cycle of poverty and dependency and from becoming self-reliant. He also noted that people in the community needed to be involved in their own development.

A lack of church unity was mentioned by several respondents as a key hindrance in mobilisation. In addition, the failure of congregations to work together within a specific community was identified as a key issue. This was one of the main findings in terms of hindrances to effective mobilisation. Some tried but it did not seem to work. What was especially striking in the poorer communities is the fact that ministers sounded disheartened and discouraged about the lack of unity with regard to these issues:

'We tried but it doesn't work. Because you find there is no unity among the churches that are around, you see? Although we are in the same place but we do things in a different way, yabona ...' ( $\operatorname{Rev} 3)$

'We've become so fragmented and we've drifted apart and that it's each one in his little corner doing his own thing. So there are occasions, which are very rare ... um ... when churches do get together to celebrate all of that and to share that experience. But we are not pooling our resources to do it and I think if we are able to do that ... the response will be greater and the impact will be greater also in the community.' (Rev 4)

'One of the saddest things in the Body of Christ world over is denominationalism. It's very bad ... we have crated so much demarcation.' (Rev 1)
Perhaps an important finding for FBOs and NGOs partnering or seeking to work with local congregations is that NGOs can disempower the local congregations from taking ownership of the issues as some ministers noted. In this scenario, the NGO or FBO becomes the service provider for social development, which affects an understanding of being missional with regard to the laity. It was, nevertheless, acknowledged by one of the ministers (a former NGO worker) that the disempowerment of local congregations by NGOs or FBOs, while attempting to become service providers for social development, was both a concern and a complex issue:

'It's hard for NGO's. There's a natural drift to fix the problem because NGOs are full of activists by definition; so, there is always going to be a drift of let's fix the problem rather than let's equip the church to fix the problem and that's hard and I say that as someone who has done that myself. Churches get busy doing everything and social needs need to be addressed; it's very complex, I don't have an answer to that.' (Rev 11)

A minister of a wealthier congregation noted that, while his church wanted to partner with FBOs, 'we don't just want to throw money at them ... How do we develop sustainable relationships that are real partnerships, you know?' (Rev 7). The expected concerns about the lack of skills and resources of certain enthusiastic but ill-equipped volunteers (especially in cross-cultural and cross-racial cases) were also mentioned: 'you know it was a bunch of ladies who were very enthusiastic but not always very wise ... sometimes there is more enthusiasm than wisdom' (Rev 2). One township pastor ( $\operatorname{Rev} 3$ ) noted that when laity had been abused by their previous pastor, they become reluctant to engage in the programmes of their new church. According to Rev 3, this hinders volunteerism.

\section{'Helps' to congregational mobilisation}

It is not surprising that one of the greatest hindrances to mobilisation is also one of the greatest 'helps' to it. Partnerships with other congregations and FBOs were, in this case, noted as a key 'help' in church mobilisation. In fact, the apartheid era was noted as a time when churches stood together as Rev 4 puts it, 'we fought together and people supported each other. There was a common cause'. Two ministers who were part of a denominational partnership (where a wealthier white congregation was partnering with, for example, a poorer coloured congregation) noted that this was successful $(\operatorname{Rev} 5 ; \operatorname{Rev} 1)$. However, they indicated that it was also important to recognise issues of power and restitution within the South African context. Partnering with poorer congregations were also seen by the minister of the wealthier church as beneficial to his congregation. Here, Rev 5 had this to say:

'We intentionally partnered with groups of people who are economically poor because we recognise that that ... we can learn something from them in terms of relational issues because I think that's where we are poor.' 
One minister, Rev 6, preferred to learn from congregations that are doing this kind of work rather than learning from FBOs. In this regard, one majority white affiliation of congregation was mentioned as a desirable learning partner. This is not surprising considering their current mobilisation model, which consisted of helping laity to check their prejudices and listen deeply to the context. This could be a church-wide initiative filtering through from small groups to preaching. It included both exposure trips to partner organisations in poorer areas and what this church terms a 'social justice course', ${ }^{15}$ which all volunteers needed to attend before volunteering with partner organisations. Of course, wealthier congregations can also employ people with development expertise, where needed, to address the fear and often incompetencies of volunteers:

'So we will employ people because we do need expertise. If we are gonna have training with pregnant moms you need good trainers but every programme we design because we believe we have to...because people are so scared. And because people don't know how to do this and they always do more harm than good. We see one of our biggest mandates is to create spaces where people can do justice.' (Rev 8)

With regard to skills development and capacity building, FBOs and NGOs were also mentioned and these were both organisations inside and outside of their congregation's geographical community. The role of the $\mathrm{CCC}^{16}$ Disaster Response team was also noted as a key platform for activating and mobilising; it is important to note that crisis events such as the xenophobic attacks in 2008 and 2015 - were mentioned as key mobilisation points.

In less-resourced congregations, the ownership by parishioners of the projects and their contributions - no matter how small - was connected with project sustainability. It was particularly encouraging to note the following story with regard to a large feeding scheme in Gugulethu:

'It's coming from the meagre resources that we have from my pensioners from the congregation. I think this is one thing they can be proud of, they are doing this work, I always say to them I think you should be proud of yourselves when you [sic] see these projects now developing.' (Rev 4)

This same minister encouraged members of his congregation that every person has the 'responsibility to alleviate poverty' and, in so doing, motivated them to get jobs for the unemployed. Similarly, Rev 9 encouraged his congregation to give whatever they could afford to these projects. Smallscale success stories, especially in poorer communities, were seen as providing hope. An interesting story to note was that of one minister in an under-resourced area who continues to train and empower identified individuals within his realm of influence. Although this may seem small, ministers are often constrained from involvement in large projects but are usually natural mentors.

15.This course seeks to conscientise congregants with regard to social justice issues within the South African context as well as the biblical imperative to respond.

16.Christian Council of Churches. This is an ecumenical group, which consists of both ecumenical and evangelical churches in Cape Town.
The role of the minister was also a key finding. This did not only concern preaching about the issues of poverty and social justice but also emerged spontaneously from the findings. One minister noted:

'It's primarily relational because my experience is you can preach 'til you are blue in the face but if you don't back it up relationally, then people just don't get it. So, I try in preaching to give theology and a scriptural framework for it, but I'll be encouraging people trying to use teaching moments ...' (Rev 11)

In this scenario, it means that the minister is actually part of the social action team. Another important point raised was that of insisting that all of the church leadership team understood God's heart for justice - be it pastors, heads of departments or cell group leaders (Rev 8). Sources of engaging in social justice and action initiatives included minister's denominational traditions, scripture and even the liturgical calendar, which often included a day or month of compassion in the mainline churches. This day or month of compassion is then used as a springboard from which to reflect and act on poverty $(\operatorname{Rev} 6, \operatorname{Rev} 10)$.

Perhaps the most notable finding was the minister's recognition of the need to 'tap into' the Ubuntu spirit found in poorer communities to help them support one another and encourage them to share whatever they have although it may not be much ( $\operatorname{Rev} 10, \operatorname{Rev} 9)$.

\section{Conclusion}

The study revealed 'more of the same issues' in terms of international and local studies with regard to the congregational responses to diaconia in addition to some interesting pointers of more effective congregational praxis. While most congregations in the world still appear because of the lack of professionalised capacity and struggle with the delivery of professionalised services to the poor and marginalised, many of them appear to undergird the most vulnerable in communities with regard to relief work and are relatively engaged in educational and individual empowerment initiatives. In terms of international findings regarding the United States and South Africa, it is also interesting to note that partnerships between congregations were essential for effective mobilisation, yet difficult to enact. The nature of collaboration with FBOs and NGOs was another interesting finding. Here, it was revealed that, while FBOs/NGOs could serve as rallying points for engagement, they could also remove ownership from congregations with whom they were seeking to work. Despite the many barriers to engagement, ministers remained committed to using their traditions, liturgy and sermons to attempt mobilisation.

Despite common challenges across class, race and denominational affiliation (such as lack of capacity and professionalism), what emerged from these findings was the role that race, class and theology played in the how and the why of congregation's engagement and what focus it takes towards that engagement. Further studies and FBOs 
working in church mobilisation, particularly within a South African context, will need to take note of these dynamics and their intersections when seeking to promote notions of restorative justice.

\section{Acknowledgements \\ Competing interests}

The author declares that she has no financial or personal relationships which may have inappropriately influenced her in writing this article.

\section{References}

Bowers du Toit, N.F. \& Nkomo, G., 2014, 'The ongoing challenge of restorative justice in South Africa: How and why wealthy congregations are responding to poverty and inequality', HTS Theological Studies 70(2), Art. \#2022, 1-8. http://dx.doi. org/10.4102/hts.v70i2.2021

Chaves, M. \& Tsitos, W., 2001, 'Congregations and social services: What they do, how they do it, and with whom', Nonprofit and Voluntary Sector Quarterly 30(4), 660-683. http://dx.doi.org/10.1177/0899764001304003
Clarke, G., 2006, 'Faith matters: Faith-based organisations, civil society and international development', Journal of International Development 18, 835-848. $\mathrm{http}: / / \mathrm{dx}$.doi.org/10.1002/jid.1317

Davids, I., Theron, F. \& Kealeboga, J.M., 2009, Participatory development in South Africa: A development management perspective, Van Schaik, Pretoria.

Farnsley, A.E., 2003, Rising expectations: Urban congregations, welfare reform and civic life, Indiana University Press, Bloomington, IL.

Gill, T.A., 2014, 'Editorial', The Ecumenical Review 66(3), 249-252. http://dx.doi. org/10.1111/erev.12114

Jeavons, T.H., 2000, 'Understanding congregations as voluntary organisations', Non-Profit Management and Leadership 10(4), 457-462. http://dx.doi.org/10.1002/nml.10408

Phiri, I. \& Dongsung, K., 2014, 'Called to be a diaconical community through a pilgrimage of justice and peace', The Ecumenical Review 66(3), 252-264. http:// dx.doi.org/10.1111/erev.12103

Swart, I., 2012, 'Are the rising expectations realistic? Local churches and social welfare in South Africa and Paarl', in I. Swart, J.C. Erasmus, P. Pettersson, F. Bosman \& A. Gouws (eds.), Welfare, religion and gender in post-apartheid South Africa Constructing a South/North dialogue, Sun Press, Stellenbosch.

Swart, I. \& Venter, D., 2001, 'NGO's and churches: Civil society actors and the premise of fourth generation development in South Africa', in J.K. Coetzee, J. Graaf, F. Hendricks \& G. Wood (eds.), Development: Theory, policy and practice, pp. 483-496.

The Warehouse, n.d., Our hope, viewed 26 June from http://www.warehouse.org.za/ index.php/site/overview/C52

Todd, N.R. \& Allen, N.E., 2011, 'Religious congregations as mediating structures for social justice: A multi-level examination', American Journal for Community Psychology 48(4), 222-237. http://dx.doi.org/10.1007/s10464-010-9388-8 